Helsingin yliopiston kasvatustieteiden osaston maaraamän virallisen vastaväittäjän lausunto fil.lis. Yrjö Engeströmin väitöskirjatutkimuksesta Learning by expanding. An activity - theoretical approach to developmental research, kesäkuu 1987.

Yhteenvetoni jakautuu kahteen osaan, väitöskirjan sisällön suppeaan kuvailuun ja arvioivaan yhteenvetoon.

\section{Kuvaileva yhteenveto}

Tämä väitöskirja käsittelee ongelmaa, joka on yhtä vanha kuin psykologiatiede itse, nimittäin opinalan jakautumista kahteen tieteeseen, jotka käyttävät keskenään yhteensopimattomia metodologioita. Tämän työn suuri voima on siinä, että se sekä tarjoaa ensyklopedisen erittelyn tämän kriisin monitahoisista ilmentymistä useilla psykologian haaroilla (mukaan lukien kognitiivinen, kehitys-, työ- ja kliininen psykologia) että tarjoaa laajan kokoavan metodologian tämän kriisin voittamiseksi erityisellä psykologisen muutoksen mekanismien ymmärtämisen alueella. Käsite "ekspansiivinen oppiminen" viittaa Engeströmin kokoavaan vaihtoehtoon.

Väitöskirja jakautuu viiteen lukuun, joista ensimmäisessä luonnehditaan ongelmaa useiden sen tällä hetkellä merkittävien ilmentymien kautta ja joista viimeisessä kootaan luvuissa 2-4 kehitelty uusi metodologinen lähestymistapa.

Väitöskirjan käsittelemän kriisin tunnuspiirteet tulevat esiin sarjassa toisiinsa kietoutuneita kaksijakoisuuksia. Nämä kaksijakoisuudet voidaan jäljittää ainakin Wundtiin asti, joka esitti, että tarvitaan kaksi psykologiaa, selittävä ja kuvaileva, jotta voidaan käsitellä kaikkia inhimillisen psykologisia prosesseja. Kuten Engeström yhteenvetona esittää, selittävä lähestymistapa, silloin kun sitä sovelletaan psykologisen muutoksen ongelmaan, turvautuu oppimisen käsitteeseen, käyttää muutosprosessin kuvaamisessa mekaanisia vertauskuvia ja saavuttaa parhaat tuloksensa selittäessään, kuinka organismit sopeutuvat ympäristönsä tapahtumiin. Kuvailevan lähestymistavan huomion keskipisteenä on ajatus kehityksestä luovana prosessina, jonka ai- kana syntyy laadullisesti uusia struktuureja. Se käyttää orgaanisia/biologisia vertauskuvia kuvaillessaan muutosprosessia, joka nähdään vallitsevien olosuhteiden ylittämisenä.

Kumpaakin lähestymistapaa arvostellaan oikeutetusti, ensinmainittua sen kyvyttömyydestä selittää, kuinka laadullisesti uudet käyttäytymismallit syntyvät ja toista sen taipumuksesta mystiikkaan ja epätäsmällisyyteen. Tässä kritiikissä käsitellään muita haitallisia kaksijakoisuuksia eritoten yksilön ja kollektiivin välistä, sisäisen ja ulkoisen välistä ja epähistoriallisen/ yleisen ja historillisen/erityisen välistä. Engeström pyrkii voittamaan nämä toisiinsa kietoutuvat kaksijakoisuudet luomalla kokoavan metodologian, jokka osoittaa mahdollisuuden kuvata ja eritellä tieteellisesti olosuhteet ylittäviä (ekspansiivisia) muutosprosesseja.

Luvun 2 ensimmainen osa palaa kaksijakoisuuden on- 
gelmaan Engeströmille keskeisellä alueella, oppimisessa ja kehityksessä, ja esittelee perusajatuksen, jota hän käyttää välttääkseen osoittamansa rajoituksen - kolmannen jäsenen tuomisen perusrakennekaavioon kulttuurisesti välitetyn inhimillisen toiminnan käsitteessä. Hän jäljittää kolme "sukuhaaraa", joissa käytetään kolmeosaista perusmallia ihmismielestä: semioottisen välittymisen filosofisen tradition, symbolisen interaktionismin psykologisen tradition ja välittyneen toiminnan teorian filosofis-psykologisen tradition. Keskeinen tässä analyysissä esille nouseva ongelma on, että kaikki yllämainitut lähestymistavat, kolmiosaisesta rakenteestaan huolimatta, pyrkivät suosimaan jotakin peruskolmion kaksijakoisuuksista. Tasapainoisen kolmijäsenisen rakenteen säilyttäminen muodostuu uuden metodologian avainvaatimukseksi.

Luvun 2 toinen osa kehittelee Engeströmin inhimillistä toimintaa kuvaavan perusrakennemallin inhimillisen toiminnan ilmaantumisesta siirtymässä apinasta homo sapiensiksi. Tämä malli eroaa aikaisemmista "kolmijäsenisistä" lähestymistavoista sikäli, että se yhdistää yhteen ainoaan struktuuriin edeltäjien erilliset kolmiomallit. Lisäksi se tarjoaa systemaattisen heuristisen menetelmän muutoksen tutkimiseksi järjestelmän sisällä osoittamalla, kuinka ristiriidat perusrakenteen eri solmukohdissa tai solmukohtien välisissä suhteissa "epätasapainottavat" rakenteen ja luovat ennakkoedellytykset uusien toimintajärjestelmien kehittymiselle.

Luvun 2 kolmannessa osassa esitetään muutoksesta vastaansanomattomia esimerkkejä, jotka keskittyvät koulutukseen, työhön, tieteeseen ja taiteeseen. Kunkin alan ekspansiivisesta oppimisesta esitetään kaaviomallit, joiden avulla näytetään, miten kukin niistä kasvaa ristiriidoista, jotka "työntävät esiin" uusia toimintarakenteita jostakin aiemmin tässä luvussa esitetyn perustoimintamallin solmukohdasta.
Luvun 2 lopussa nostetaan jälleen esiin sama ongelma kuin luvun alussa, kysymys siitä, kuinka uudet rakenteet syntyvät ihmisen yksilönkehityksessä, mutta tällä kertaa niin, että toiminnan teoria tuodaan mukaan mahdollisena vaihtoehtoisena selitysmallina. Engeström suhtautuu kriittisesti olemassa oleviin aihetta käsitteleviin toiminnanteoreettisiin lähestymistapoihin, joissa ei hänen mukaansa ole riittävästi nivelletty toisiinsa yksilöllisellä ja yhteiskunnallisella tasolla tapahtuvaa muutosta. Hän osoittaa myös, miten vaikeata on kohdata oppimistoimintaa koululuokissa (Piagetin ja Davydovin aiemmin hyvin eri tavalla merkille panema vaikeus). Nämä ongelmat johtavat kehitysmuutoksen käsittelyyn luvussa 3 ja erityisesti ongelmaan, miten uusi syntyy.

Luvussa 3 keskitytään selittämään ekspansiivisen oppimiseen liittyviä vaiheittaisia muutoksia. Jälleen käsitellään oppimisen ja kehityksen välistä perusongelmaa ja ratkaisua etsitään havainnosta, että toiminnalla on hierarkinen rakenne, johon yhdistyy yksilön ja sosiaalisen ryhmän välisen suhteen kaksinaisluonne. Kehitys nähdään siirtyminä yhdeltä toiminnan tasolta toiselle (ekspansio) ja siinä tavassa, jolla yksilöt muuttavat olemassa olevaa toimintajärjestelmää osana omaa kehitysprosessiaan

Kun nämä prosessit yhdistetään, tuloksena on "kehitysspiraali", joka johtaa tarvetilasta (ensisijainen ristiriita) kaksoissidokseen (toissijainen ristiriita), välineelliseen, tavoitteelliseen tekoon, joka johtaa tilapäiseen ratkaisuun ja lujittumisen jaksoon kunnes syntyy uusia ristiriitoja ja prosessi alkaa uudestaan. Näitä ajatuksia havainnollistetaan kahden kaunokirjallisen esimerkin avulla.

Tämän luvun merkittäviin käsitteellisiin ansioihin kuuluu käsitteen "lähikehityksen vyöhyke" laajentaminen niiden tapausten ulkopuolelle, joissa tietävämpi, voimakkaampi "toinen" edesauttaa lapsen kehitystä, sellaisten sosiaalisten käytäntöjen tasolle, jotka toimivat välittäjinä yhteiskunnan nykyisten toimintamuotojen ja sellaisten tulevien muotojen välillä, jotka syntyvät kollektiivisena vastauksena vallitseviin ritiriitoihin. Tämä uudelleenmuotoilu osoittaa Engeströmin pyrkimystä luoda sellaista "itsensä suosta nostamisen" metodologiaa, joka tekee mahdolliseksi luoda uutta tietoisesti. Olennaista tällaisessa prosessissa on ekspansiivisen oppimisen välineiden tunnistaminen, ongelma, jolle luku 4 on omistettu.

Luvussa 4 luodaan katsaus "ajattelun välineiden" histori alliseen kehitykseen etsittäessä välineitä, jotka vastaisivat ekspansiivisen oppimisen nousemista hyväksyttäväksi kulttuuriseksi käytännöksi. Yleiseksi välineeksi Engeström esittää uutta, Hegelin ja tiettyjen nykyisten neuvostopedagogien/filosofien ajatuksiin perustuvaa käsitystä käsitteistä abstraktista konkreettiseen kohoamisen prosessina.

Kolme "toissijaista" välinettä täydentää tätä käsitteitä koskevaa peruslähestymistapaa: ponnahduslaudat, mallit ja mikrokosmokset. Näitä ideoita valaistaan tieteen historiasta otetuin esimerkein (Mendelejevin jaksollista järjestelmää koskeva keksintö, atomiytimen halkaisemisen keksintö ja atomipommin rakentaminen).

Luvussa 3 ja 4 esiin nouseva merkittävä kysymys on ekspansiivisen oppimisen prosessin pitkä ajallinen ulottuvuus. Yksilön kehityksessä muutossykli saattaa vaatia kuukausia, yhteiskunnalliskulttuurisessa muutoksessa se saattaa viedä vuosikymmeniä tai -satoja. Kuinka se silloin voi olla aktuaaliempiirisen tutkimuksen kohteena teoreettisen ja historiallisen tutkimuksen lisäksi?

Engeström vastaa kysymykseen esittämällä vaiheittaisen tutkimusstrategian, jota hän nimittää ekspansiivisen kehittävän tutkimuksen metodologiseksi sykliksi. Tällaista tieteellisen toiminnan muotoa ei voida rajata yksinomaan 
perinteisiin psykologisiin menetelmiin, vaan siinä täytyy jälleen omaksua menetelmiä, joita naapuritieteet (sosiologia, antropologia jne.) sovelsivat silloin, kun psykologia syntyi ja sen menetelmäkriisi alkoi.

\section{Arvioiva yhteenveto}

Tämä väitöskirja on älyllinen voimannäyte, joka antaa merkittävän panoksen psykologian, kasvatustieteen ja useiden lähialojen pitkäaikaisten teoreettisten ja menetelmällisten ongelmien ratkaisemiseen. Kuvailevassa yhteenvedossa totesin, että alaamme vaivaavien kaksijakoisuuksien voittamiseen käytetään toiminta-lähestymistapaa. Tässä totean, että Engeströmin tapa lähestyä toiminnan teoriaa on ainutlaatuinen siinä, että toiminnasta tehdään siinä aito "kolmas osapuoli" tämän hetken psykologisessa keskustelussa tieteenalan kehityksestä. Hän osoittaa tämänkaltaisen teorian kehittelyssä senlaatuista vaikeiden teoreettisten ja metodologisten kysymysten tuntemusta ja käsityskykyä, joka asettaa hänet korkealle arvoasteikossa sellaisten nykyajan kognitiivisen psykologian edustajien joukossa kuin oman yliopistoni Donald Norman tai Neuvostoliiton Vladimir Zinchenko.

Toiminnan teoriaan tutustuneet tietävät, että se esitetään usein "periaatteessa" filosofis-menetelmällisenä vaihtoehtona olemassa oleville psykologisille lähestymistavoille, jotka alistetaan murskaavalle kritiikille ja hylätään. Hyvin usein toiminnan teorian omaksuminen julistetaan reduktionistisen psykologian ideologiseksi kumoamiseksi. Engeström ei lähde mukaan näihin yksipuolisiin lähestymistapoihin. Hänen lähestymistapansa suurena ansiona on, että hän näkee tarvittavan aitoa synteesiä, ei menneen yksipuolista hylkäämistä.

On vaikea antaa kuvaa siitä, miten vaikuttava Engeströmin laaja tapa käsitellä psykologista teoriaa on. En tunne yhtään yhtä laajaa ja syvää tämän aiheen tutkimusta. Hänen tietonsa kognitiivisesta psykologiasta ja kehitysteorioista ovat samanaikaisesti historiallisessa perspektiivissä syviä, sangen ajanmukaisia sekä erinomaisen analyyttisiä: monia osia tästä väitöskirjasta voitaisiin julkaista amerikkalaisissa aikakauslehdissä yksinkertaisesti siksi, että ne ovat korkealaatuisia kriittisiä katsauksia ja niissä kyetään verrattomalla tavalla käsittelemään niin englanniksi kuin saksaksi, venäjäksi, ruotsiksi ja suomeksi julkaistuja teoksia osoittaen niiden väliset aidot yhteydet.

Vielä suuremman vaikutuksen minuun on tehnyt Engeströmin kyky yhdistää aineksia, jotka ulottuvat kauas psykologian ulkopuolelle, kun hän rakentaa uutta metodologista järjestelmäänsä: ajattelen tässä sitä, kuinka erinomaisesti hän on hyödyntänyt semioottisten filosofien, Marxin, Hegelin ja neuvostoliittolaisen tradition parhaiden edustajien, Habermasin ja saksalaisten toiminnan teorian edustajien työtä sekä sitä, mikä on olennaista pedagogisessa teoriassa, antropologiassa, arkeologiassa, tieteen historiassa ja kirjallisuuskritiikissä. Näitä kauas ulottuvia lähteitä ei koskaan oteta mukaan itsetarkoituksellisesti; ne rikastuttavat ja vahvistavat esitettyä väitettä.

Kuten Engeström varsin oikein toteaa, on luotava uudenlainen empiirinen tutkimuskäytäntö hänen julista- miensa metodologisten periaatteiden toteuttamiseksi. Odotan innolla tätä vaihetta hänen työssään.

Kaiken kaikkiaan lisensiaatti Engeströmin työ osoittaa psykologian ja kasvatustieteen tieteellisen tutkimuksen korkeimpia laatuominaisuuksia. Sen tulokset luovat perustan oppimisen ja kehityksen välisen suhteen ratkaisemattoman ongelman ratkaisemiselle tavalla, jota pitäisi välittömästi soveltaa kasvatuskäytännön ja työn organisoinnin tärkeillä aloilla. Lisäksi sen kokonaisrakenne onnistuu yhdistämään uudestaan psykologian yhteensopimattomat osat niin, että sellaisilla tärkeillä inhimillisen elämän aloilla kuin taiteella ja kirjallisuudella on aito sijansa psykologian ja kasvatustieteen teoriassa sen sijaan, että ne toimisivat esoteerisina etuvartijoina. Näin ne rikastavat tulevan ihmisluontoa koskevan teorianmuodostuksen mahdollisuuksia.

Lisensiaatti Engeström puolusti työtään erittäin ansiokkaasti. Esitän varauksetta, että lisensiaatti Engeströmin väitöskirja hyväksytään korkeimpaan akateemiseen arvoon oikeuttavana opinnäytteenä.

\section{Michael Cole University of California, San Diego}

